\title{
Emergent chemical in sewage treatment plant: di-(2-ethylhexyl) phthalate
}

\author{
E. Lovatel ${ }^{1}$, L. Calábria ${ }^{2}$ \& I. Nascimento ${ }^{3}$ \\ ${ }^{1}$ Chemical Engineering Department, University of Caxias do Sul, Brazil \\ ${ }^{2}$ Materials post-graduate program, University of Caxias do Sul, Brazil \\ ${ }^{3}$ Center of Exact Sciences and Technology, \\ Institute of Environmental Sanitation, University of Caxias do Sul, Brazil
}

\begin{abstract}
In this work a simple gravimetric method was described for the study of di-(2ethylhexyl) phthalate (DEHP) in wastewater samples from the inflow and outflow points of the sewage treatment plant (ETE) at the University of Caxias do Sul (UCS). The organic phase of the sample was precipitated by adding concentrated $\mathrm{HCl}$. The precipitate was filtered in glass columns packed with treated cotton. After drying, the columns containing the precipitate were carefully weighted and extracted with n-hexane. After solvent evaporation, the organic extract was re-diluted and analyzed by Gas Chromatography with Flame Ionization Detection (GC/FID). The average rate of DEHP removal was $27.50 \%$. The median DEHP concentration was $6.01 \mu \mathrm{g} \mathrm{mL}^{-1}$ at the outflow point. This DEHP concentration is well above the maximum concentration level reported in the literature.
\end{abstract}

Keywords: plasticizers, liquid residues, GC/FID, DEHP.

\section{Introduction}

Plasticizers are organic esters added to polymers to facilitate processing and to increase flexibility and toughness of the final product by internal modification of the polymer molecule. Some of these compounds are called phthalates and dominate polymer production. DEHP in many cases is the sole general-purpose plasticizer produced.

DEHP can interfere in the functioning of the endocrine system and in the action mechanism of hormones. They are called endocrine deregulators or 
endocrine disruptors and can cause the following problems: reproductive anomalies (morphological and functional gonadal dysfunction, e.g., infertility and decreased libido) and congenital malformations [1-3]. Bornehag and coworkers [4] found associations between dust concentrations of specific phthalate esters in house dust and asthma, rhinitis, and eczema in children. Phthalate esters were also studied in the serum of young Puerto Rican girls with premature breast development [5]. High levels of dimethyl, diethyl, dibutyl, and di-(2-ethylhexyl) phthalates and their main metabolite mono-(2-ethylhexyl) phthalate were as detected in $28(68 \%)$ samples from the larche patients. The long term exposure to high levels of DEHP can produce damages to the liver and testicles in mammals and cause death in aquatic species. Bisphenol A, another important plasticizer, is suspected of acting as an environmental estrogen [6]. Plasticizers can also influence the mobility and bioavailability of toxic substances like polychlorinated biphenyls and metal ions by changes in their water or lipid solubility [7].

As DEHP is used specially in soft polyvinyl chloride production [6], it is widespread in all environments, since it is used in packaging, clothes, films, paints, adhesives, cosmetics, ink printers and many other products. One of the main forms of exposure to phthalates is through food, in addition to medical materials and by occupational contact [8]. On the other hand, DEHP was also detected in mineral, ultra pure and tap waters [9]. Other kinds of samples where DEHP was detected are: municipal solid waste compost [10], sewage and wastewater treatment sludge [11], river sediments [7], landfill leachate [6, 12, 13] and swine slaughterhouse wastewaters [14], among others.

Most of the DEHP concentration that enters the treatment plants remains adsorbed to the waste sludge and suffers biodegradation [15]. On the other hand, the DEHP remaining in the aqueous phase is much less biodegraded. In this way, plasticizers can persist in the environment and contaminate superficial and groundwater.

A number of studies have shown the removal of phthalates in wastewater treatment plants [16-18]. The sample extraction methods in those and several other works were based on liquid-liquid extraction (LLE) or solid-phase extraction (SPE). In the LLE the employment of larges volumes of sample (1 $2 \mathrm{~L}$ ) and organic solvents and the recovery grade and detection limit depend on solvent purity. SPE has the advantage of a great reduction of the sample volume (usually $100 \mathrm{~mL}$ ), but the extraction of water samples containing solids or heavily contaminated by particulate matter can block the cartridges and the previous sample must be filtered. The SPE can also be performed with disks replacing the cartridges but the sample's volume is drastically enhanced (3 L). In a solventless extraction method called SPME $[19,20]$, for the extraction of semivolatile compounds, such as pesticides, PAHs and phthalates from aqueous matrices, only compounds with high octanol-water partition coefficients $\left(\mathrm{K}_{\mathrm{ow}}>4\right)$ can be extracted with high recovery grade. Thus, simple and low cost aqueous samples extraction methods that require minimum amounts of sample and organic solvents are still needed. 
The main objective of this work is to investigate the presence of DEHP at inflow and discharge points of a sewage treatment plant, using a simple gravimetric method modified from the one proposed by Thurman and Malcom [21] for sample extraction. The instrumental analysis was performed by Gas Chromatography with Flame Ionization Detection.

\section{Materials and methods}

The physical-chemical characteristics of the samples are shown in Table 1.

Table 1: $\quad$ Physical-chemical characteristics of the samples $\left(\mathrm{mg} \mathrm{L}^{-1}\right)$.

\begin{tabular}{|c|c|c|c|c|c|c|}
\hline \multicolumn{7}{|c|}{ Extraction } \\
\hline Inflow & 1 & 2 & 3 & 4 & 5 & Average \\
\hline QOD & 612 & 632 & 1879 & 610 & 282 & 803 \\
\hline BOD & 433 & 407 & 784 & 389 & 137 & 430 \\
\hline Suspended Solids & 51 & 71 & 136 & 153 & 45 & 91.2 \\
\hline Outflow & 1 & 2 & 3 & 4 & 5 & Average \\
\hline QOD & 72 & 44 & 111 & 99 & 149 & 95 \\
\hline BOD & 51 & 62 & 82 & 57 & 34 & 57.2 \\
\hline Suspended Solids & 63 & 44 & 56 & 99 & 92 & 70.8 \\
\hline
\end{tabular}

\subsection{Samples and materials}

The ETE-UCS treats, exclusively, $100 \mathrm{~m}^{3} / \mathrm{d}$ of sewage generated at the university (ca. 20,000 people). The treatment system comprises an aeration lagoon (hydraulic residence time: $4 \mathrm{~d}$ ), a sedimentation lagoon (hydraulic residence time: $2 \mathrm{~d}$ ) and two maturation lagoons (total hydraulic residence time: $26.9 \mathrm{~d}$ ). Monthly (from December 2007 to April 2008) wastewater samples (6 L) were collected from the sewage treatment plant of the Caxias do Sul university located in Caxias do Sul, Rio Grande do Sul, southern Brazil, in glass bottles (1 L capacity) with caps protected by aluminum foil to prevent contamination. The sampling period was from 8:00 am to 8:00 pm, every $2 \mathrm{~h}$. All the samples were mixed and $1 \mathrm{~L}$ sample was collected from the mixture (composite sample). The samples were filtered at low pressure, maintained at $4{ }^{\circ} \mathrm{C}$ and protected from light until the extraction procedures (at maximum $24 \mathrm{~h}$ after the collection). All the solvents were distilled twice in glass apparatus. All reagents and solvents were of analytical grade and distilled twice in a glass apparatus, when necessary. All glass material was washed with n-hexane, acetone and dichloromethane and dried at $120{ }^{\circ} \mathrm{C}$ for $4 \mathrm{~h}$. Plastic or rubber materials were not used to avoid contact with samples or solvents.

\subsection{Sample extraction}

The sample extraction was a modified version of the one proposed by Thurman and Malcom [21] for the isolation of aquatic organic substances and utilized by 
Calace and Petronio [22] for the characterization of high molecular weight organic compounds in landfill leachate. The extraction procedures were as follows:

a) A volume of $100 \mathrm{~mL}$ of the sample was acidified (until $\mathrm{pH} \sim 2$ ) with concentrated $\mathrm{HCl}$ and magnetically stirred for $15 \mathrm{~min}$;

b) After precipitation of the organic phase (ca $20 \mathrm{~min}$ ), the sample was filtered in a glass column $(7.0 \mathrm{~cm}$ long $x 1.0 \mathrm{~cm}$ i.d.) packed with 1.0 gram of cotton previously extracted (Soxhlet extraction by $4 \mathrm{~h}$ with n-hexane);

c) After drying $\left(4 \mathrm{~h}\right.$ at $\left.35^{\circ} \mathrm{C}\right)$ the organic phase was extracted with $5 \mathrm{~mL}$ of n-hexane;

d) After volume reduction to $1.0 \mathrm{~mL}$, the organic extract was analyzed by Gas Chromatography.

\subsection{Instrumental analysis}

A Perkin Elmer Gas Chromatograph model Autosystem XL, with Flame Ionization Detector was used for identification and quantification of DEHP by the internal normalization method. An Elite-5 fused silica capillary column (30 m x $0.25 \mathrm{~mm}$ i.d. crossbond 5\% diphenyl - 95\% dimethyl polysiloxane, $0.25 \mu \mathrm{m}$ film thickness) was used for the GC separation using the following oven temperature program: $150^{\circ} \mathrm{C}(5 \mathrm{~min}$ hold $)$ heating to $220^{\circ} \mathrm{C}$ at $3{ }^{\circ} \mathrm{C} / \mathrm{min}$ and heating to $300^{\circ} \mathrm{C}$ at $10^{\circ} \mathrm{C} / \mathrm{min}(5 \mathrm{~min}$ hold $)$. The injector temperature was $250^{\circ} \mathrm{C}$. The volume of $1.0 \mu \mathrm{L}$ was injected (triplicate of injection) in the split mode $(1: 50)$.

\subsection{Recovery grade and detection limit}

The recovery grade was measured by the extraction of a real sample spiked with a DEHP standard solution (resulting in a net concentration of DEHP of $20 \mu \mathrm{g} \mathrm{mL}$ $\left.{ }^{1}\right)$. The detection limit was evaluated by successive dilutions of a DEHP standard solution $\left(100 \mu \mathrm{g} \mathrm{mL}^{-1}\right)$.

\section{Results and discussion}

Figure 1 show the extraction blank chromatogram, where no peak of DEHP was detected.

Typical chromatograms of the organic extracts of the entrande and exit points are shown in Figure 2.

The detection limit was $0.5 \mu \mathrm{g} \mathrm{mL} \mathrm{m}^{-1}$ and the detector response was linear between 0.5 and $25 \mu \mathrm{g} \mathrm{mL}^{-1}\left(\mathrm{R}^{2}=0.97\right.$; equation: $\left.\mathrm{y}=3.726 \mathrm{x}+7.384\right)$.

The recovery grade was $75.95 \%( \pm 5.13)$ and lower than the $95 \%$ reported by Ballesteros et al. [23] but those authors employed more complex sample extraction and preparation methods (Solid-phase extraction and silylation) and Gas Chromatography with Mass Spectrometry detection (GC-MS). 


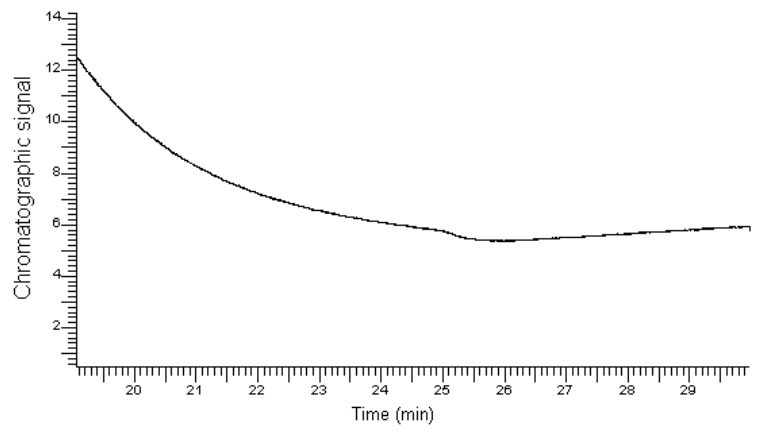

Figure 1: Extraction blank chromatogram.

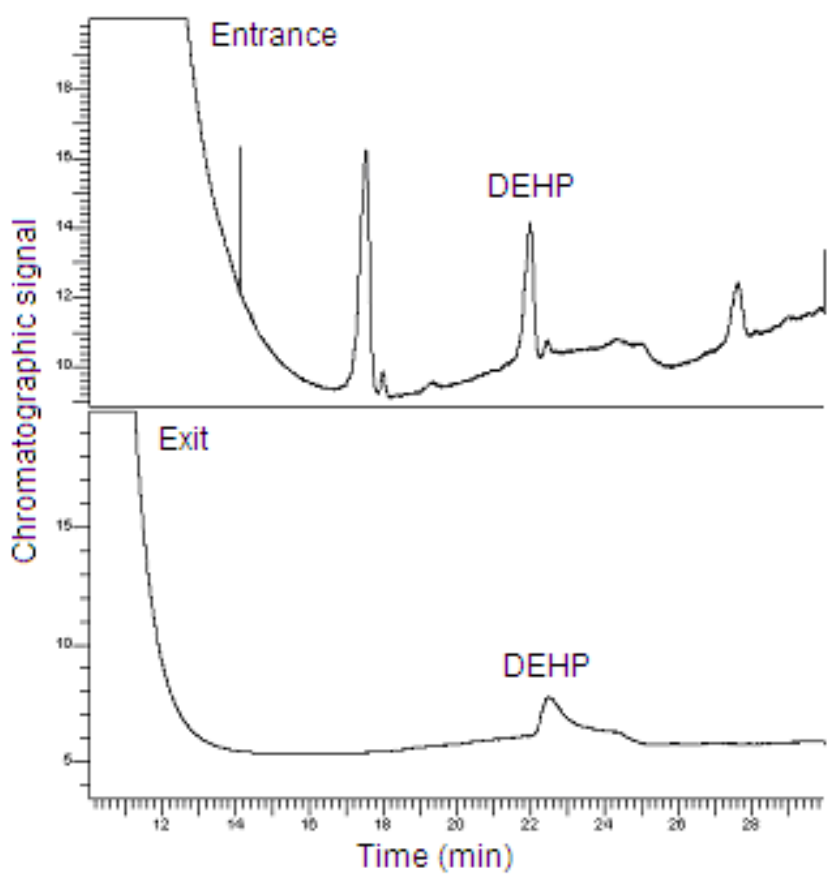

Figure 2: Chromatograms of the organic extracts of the ETE inflow and outflow points.

At the inflow point, the median concentration of DEHP was $8.29 \mu \mathrm{g} \mathrm{mL}^{-1}$ and the concentrations ranged from $3.50( \pm 0.90)$ to $26.83( \pm 2.69) \mu \mathrm{g} \mathrm{mL}{ }^{-1}$. At the outflow point the median concentration was $6.01 \mu \mathrm{g} \mathrm{mL}^{-1}$ and the concentrations ranged from $3.49(\tilde{ \pm} 0.95)$ to $20.89( \pm 1.16) \mu \mathrm{g} \mathrm{mL}^{-1}$.

The median DEHP concentration found in our work at the outflow was much higher than the $0.72 \mu \mathrm{g} \mathrm{g} \mathrm{\textrm {L } ^ { - 1 }}$ found by Furtmann [16] in industrial sewage wastewaters. The DEHP removal grade $(27.50 \%)$ was lower than the $90 \%$ 
reported by Paxéus et al. [17]. These results make it quite clear that the treatment system of the ETE-UCS will require much improvement as far as DEHP removal is concerned.

Since DEHP has water solubility as low as $5.10 \times 10^{-4} \mathrm{mg} \mathrm{L}^{-1}$ [24], a high adsorption of this chemical to the surface of the suspended solid particles and organic matter must be expected. In the studied samples (Table 1), the QOD and BOD removals were relatively high ( 88.17 and $86.70 \%$, respectively) but the suspended solids remain high (22.37\% reduction). These sample characteristics can enhance the DEHP partitioning and explain the high median concentration of DEHP at the exit point. Yamamoto et al. [25] reported a possible relationship between relatively high BOD values of landfill leachate samples and contamination by bisphenol A (a well know plasticizer that is also suspected of endocrine disrupting action).

The PVC materials (like the tubes used in water and wastewater canalization) can be another source of DEHP contamination. According to Tienpoint et al. [26] the PVC concentration in wastewater treatment plant sludge ranged from 18 to $508 \mu \mathrm{g} \mathrm{g}^{-1}$. If plasticizers are contained within a plastic matrix, one would expect that they were not very available for biodegradation [15].

\section{Conclusions}

The gravimetric method employed in this work is very simple, with a good recovery grade and it can be applied to heavily contaminated water samples, without the limitations normally associated to the traditional extraction methods. The amounts of DEHP at the ETE-UCS outflow are well above the maximum limit allowed by official regulators, as the US-EPA, and this may be due to the physical-chemical characteristics of the sample, mainly suspended solids and organic matter content. The results suggest the need for additional treatment of the wastewater for DEHP removal and replacement of the PVC tubes of the treatment plant to avoid the post-contamination of the samples by plasticizers.

Our next step will be to evaluate how the organic matter and the PVC content can affect DEHP partitioning in the studied samples.

\section{Acknowledgements}

To CNPq for the financial support and the LASAN of the Caxias do Sul University for the physical-chemical analysis.

\section{References}

[1] Nelson, P., Epidemiology, biology, and endocrine disrupters. Occupational Environment, 60, pp. 541-542, 2003.

[2] Mantovani, A., Problems in testing and risk assessment of endocrine disrupting chemicals with regard to developmental toxicology. Chemosphere, 39, pp. 1293-1300, 1999. 
[3] Gray, J.R., Prostate cancer risk groups and comparisons: fruitless or fruitful? Journal of Clinical Oncology, 20, pp. 4129-4130, 2002.

[4] Bornehag, C., Sundell, J., Weschler, C. J., Sigsgaard, T., Lundgren, B., Hasselgren, M. \& Hägerhed-Engman, L, The Association between Asthma and Allergic Symptoms in Children and Phthalates in House Dust: A Nested Case-Control Study. Environmental Health Perspectives, 112, pp. 1393-1397, 2004.

[5] Colón, I., Caro, D., Bourdony, C. J. \& Rosario, O., Identification of Phthalate Esters in the Serum of Young Puerto Rican Girls with Premature Breast Development. Environmental Health Perspectives, 108, pp. 895900, 2000.

[6] Bauer, M.J. \& Herrmann, R., Estimation of the environmental contamination by phthalic acid esters leaching from household wastes. Science of the Total Environment, 208, pp. 49-57, 1997.

[7] Möder, M., Popp, P. \& Pawliszyn, J., Characterization of water-soluble components of slurries using solid-phase microextraction coupled to liquid chromatography mass spectrometry. Journal of Microcolumn Separation, 10, pp. 225-234, 1998.

[8] Wams, T.J., Diethylhexylphthalate as an environmental contaminant: a review. Science of the Total Environment 66, pp. 1-16, 1987.

[9] Akon, H., Yoon, B., Takayuki, K., Mariko, H., Maya, M. \& Takashi, N. Separation of endocrine disruptors from aqueous solutions by pervaporation: DEHP and butylated hydroxytoluene in mineral water. Journal of Applied Polymer Science, 94, pp. 1737-1742, 2004.

[10] Gonzalez-Vila, F.J., Saiz-Jimenez, C. \& Martin, F., Identification of free organic-chemicals found in composted municipal refuse. Journal of Environmental Quality, 11, pp. 251-254, 1982.

[11] Boyd, S.A., Sommers, L.E. \& Nelson, D.W., Infrared spectra of sewage sludge fractions - evidence for an amide metal-binding site. Journal of American Soil Science Society, 43, pp. 893-899, 1979.

[12] Nascimento, I.F, von Muhlen, C., Schossler, P. \&Caramão, E.B., Estudo de compostos orgânicos em lixiviado de aterros sanitários por EFS E CG/EM. Química Nova, 24, pp. 554-556, 2001. Abstract in English.

[13] Nascimento, I.F., von Muhlen, C., Schossler, P. \& Caramão, E.B., Identification of some plasticizers compounds in landfill leachate. Chemosphere, 50, pp. 657-663, 2003.

[14] Aguilar, C.P., Peruzzolo, M., Di Luccio, M., Dallago, R.M. \& Nascimento, I.F. Qualitative study of organic compounds in wastewaters of a swine slaughterhouse. Environmental Monitoring and Assessment, 116, pp. 103110, 2006.

[15] Staples, C.A. \& Peterson, D.R., Degradation of phthalates esters in the environment. In: Charles A. Staples (Ed.). The handbook of environmental chemistry, volume 3 Anthropogenic compounds, part Q, Phthalate esters, New York, pp 85-124, 2003. 
[16] Furtmann, K., Phthalate in der aquatischen umwelt. PhD thesis, Universität Gesamthochschule Disenberg. English Translation prepared for European Council for Plasticizers and Intermediates. Brussels, 1995.

[17] Paxéus, N., Robinson, P. \& Balmer, P., Study of Organic Pollutants in Municipal Wastewater in Goteburg, Sweden. Water Science and Technology, 25, pp. 249-256, 1992.

[18] Fauser, P., Sorensen, P.B., Carlsen L. \& Vikelsoe, J., Phthalates, nonylphenol and LAS in Rockilde wastewater treatment plant. NERI technical report, 354. National Environmental Research Institute, Denmark, 2001.

[19] Pawliszyn, J., Applications of solid-phase microextraction, RSC chromatography monographs, Royal Society of Chemistry, Letchworth, UK, 1999.

[20] Prokůpková, G., Holadová, K., Poustka, J. \& Hajšlová, J. Development of a solid-phase microextraction method for the determination of phthalic ester in water. Analytica Chimica Acta, 457, pp. 211-223, 2002.

[21] Thurman, E.M. \& Malcom, R.L., Preparative isolation of aquatic humic substances. Environmental Science and Technology, 15, pp. 463-466, 1981.

[22] Calace, N. \& Petronio, B.M., Characterization of high molecular weight organic compounds in landfill leachate: humic substances. Journal of Environmental Science and Health, Part A, 32, pp. 2229-2244, 1997.

[23] Ballesteros, O., Zafra, A., Navalón, A. \& Vílchez, J.L., Sensitive gas chromatographic-mass spectrometric method for the determination of phthalate esters, alkylphenols, bisphenol A and their chlorinated derivatives in wastewater samples. Journal of Chromatography A, 1121, pp. 154-162, 2006.

[24] Ellington, J.J., Octanol/Water Partition Coefficients and Water Solubilities of Phthalate Esters. Journal of Chemical Engineering Data , 44, pp. 1414 1418, 1999.

[25] Yamamoto, T., Yasuhara, A., Shiraishi, H. \& Nakasuki, O., Bisphenol A in hazardous waste landfill leachates. Chemosphere, 42, pp. 415-418, 2001.

[26] Tienpont, B., David, F, Vanwalleghem, F. \& Sandra, P., Pyrolysiscapillary gas chromatography-mass spectrometry for the determination of polyvinyl chloride traces in solid environmental samples. Journal of Chromatography A, 911, pp. 235-247, 2001. 